\title{
3- TRABALHO E MEDIAÇÃO DIGITAL: captura de tempo e erosão de direitos ${ }^{*}$
}

Rosangela Nair de Carvalho Barbosa

\section{Introdução}

A espiral de transformações do trabalho dos últimos 30 anos é marcada, estruturalmente, pela ampliação da superpopulação relativa e pelo aprofundamento da precariedade laboral, decorrente da flexibilização do uso da força de trabalho e da organização produtiva, com a grave erosão dos direitos do trabalho e a ampliação dos trabaIhadores supérfluos.

Dispositivos de inovação tecnológica como as TICs (Tecnologias da Informação e Comunicação) e a IA (Inteligência Artificial) têm sido fundamentais para viabilizar a referida flexibilização, embaçando as relações e as jornadas de trabalho ao passo que externaliza parte dos custos produtivos e os riscos sociais da economia mercantil para os trabalhadores.

O presente texto aborda a transformação da gestão do trabaIho, das relações e condições de trabalho a partir da mediação digital, elencando alguns de seus condicionantes fundamentais. Nessa direção, apresentamos inicialmente algumas considerações sobre a disseminação das TICs no quadro mais geral da flexibilização capitalista. Em seguida, especificamos as vantagens comparativas dessas tecnologias na medida em que foram expandidas num mercado amplo de usuários em escala global, apresentando-se como um novo negócio em si e como pressuposto da dinamização das forças produtivas de outras empresas, assim como dos modos de vida. Seguidamente tratamos especificamente da repercussão sobre o trabalho, demonstrando a contraface dessas inovações, expressa na deteriorização dos direitos, como pode ser evidenciado pelo prolongamento e pela intensificação das jornadas de trabalho.

*DOI- 10.29388/978-65-86678-47-5-f.69-106 


\section{Tecnologia e Contradição Imanente}

A disseminação da mediação digital no trabalho é parte da nova etapa de aprofundamento da reestruturação produtiva do capital, aberta nos anos de 1970, no capitalismo mundial. Portanto, é parte do ajuste do capital a sua crise estrutural (BARBOSA, 2018), iniciada naqueles anos, e que delineou uma agenda de tentativas de recomposição da taxa média de lucro, por meio da reestruturação da organização produtiva, das relações de trabalho, da aplicabilidade de trabalho vivo, da captação de investimentos financeiros, além de ditar a diminuição de fundo público destinado a proteção social e a empresas públicas. A tecnologia terá papel decisivo aí, instrumentalizando novos produtos e negócios, além de recompor os processos produtivos e de trabalho da totalidade capitalista.

Ainda que o incremento tecnológico disruptivo não seja uma novidade no sociometabolismo do capital, muito ao contrário, o acompanha como parte do próprio modus operandi da Grande Indústria, é fundamental que possamos a cada ciclo compreender suas especificidades no tocante a essência desta forma social que é a produção de valor e, nesse processo, a recomposição das contradições sistêmicas que dinamizam o capitalismo. Historicamente, a economia assentada largamente em trabalho vivo foi superada por um fundamento mais restrito, na medida em que a força de trabalho não mais governa o processo de produção, portanto, ele "depende, ao contrário, do nível geral da ciência e do progresso da tecnologia, ou da aplicação dessa ciência à produção" (MARX, 2011, p. 588), de forma que o expansionismo do valor depende do movimento crescente de inovação tecnológica (BRAVERMAN, 1977; MANDEL, 1985; HUWS, 2017).

Esse descompasso revela uma contradição imanente à lógica da forma social, que de um lado incita à acumulação crescente de capital e de outro desgasta as condições para isso, na medida em que diminui o trabalho gerador de valor. A base dessa contradição é a dinâmica da categoria fundamental mercadoria e sua antinomia de valor de uso e valor, que provoca em seu crescimento, ao mesmo tempo, o estranhamento humano e a gana automática pela autoexpan- 
são do capital, por onde se delineia a estrutura de exploração da força de trabalho e a expropriação, historicamente reposta, dos meios de vida. Essa dinâmica provoca permanentes mutações porque é incessante a busca por valor e, nesse sentido, o ímpeto por valor excedente que impõe a renovação sistemática do modo de produzir e a elevação da produtividade daí decorrente diminui o valor em cada mercadoria, redundando na disputa do capitalista individual por transferência de valor do montante social produzido. O capital fixo é usado concretamente para economizar trabalho, e, isso materialmente significa dispensar trabalho vivo, produtor de valor (FAUSTO, 1989). Portanto, a lógica da forma social envolve um reiterado estresse entre desenvolvimento das forças produtivas e relações sociais capitalistas, pois o aumento da produtividade é exigência do valor e ao mesmo tempo coloca seus limites ${ }^{1}$.

Essa tensão tem como consequência o enjeitamento do trabaIho vivo como parte do processo de produção enquanto totalidade, impelindo contingentes de trabalhadores à condição de supérfluo para a dinâmica do capital, como também, provocando a desvalorização da força de trabalho mantida ocupada. "Esse perigo ameaça não só uma crescente população descartável, que não vê oportunidade de emprego imediata, mas também a reprodução do próprio capital" (HARVEY, 2016, p.107).Este é um dos pontos cruciais da crise estrutural do capital, pois os movimentos episódicos de aquecimento econômico não eliminam aquela contradição, que governa os diferentes ciclos históricos do capitalismo, mas ao contrário a aprofunda. As TICs

\footnotetext{
${ }^{1}$ Nos termos da lei geral da acumulação, ainda que o trabalho vivo diminua em relação aos meios de produção, medidas de compensação poderiam vir da criação de novos produtos, aprofundamento de modos de exploração e desvalorização da força de trabalho, desenvolvimento tecnológico para ampliar a produtividade e ainda da ampliação das esferas da vida social sob o domínio do capital. Esses mecanismos compensatórios podem se transformar em barreira, na contemporaneidade aqui tratada, por conta da tecnologia da microeletrônica ser qualitativamente distinta, em natureza, escala e velocidade, na medida em que tornou possível colocar forças produtivas em ação com menor absorção e no limite, sem absorver, trabalho direto. Portanto, a compensação como deslocamento dos efeitos das contradições acaba reacendendo-as. Essa inflexão lógica e histórica do valor, que desapega o conteúdo da forma social, provoca disrupções bárbaras na vida social. E isso não significa que o capital é impedido de seguir gerando as condições do valor, mas o faz como dissociação reiterada da organização social, o que se manifesta como barbarismos.
} 
compõem esse universo contraditório que tratamos aqui, brevemente, nos limites desse texto.

\section{Crise de 2008 e TICs}

Para a disseminação das TICs foram fundamentais, a partir dos anos de 1980, a liberalização comercial e financeira e a formação de um gigantesco exército industrial de reserva, tornando possível uma superpopulação excedente disponível em escala mundial viabilizando a forte migração de trabalho para o sul global. Ao lado disso, Huws (2017) evidencia a tendência à forte concentração de capitais, inclusive no sul (Brasil, México, China e Índia), como parte desse processo reestruturador explosivo do capital, que desloca os efeitos e repõe as contradições.

No entanto, a demanda pela digitalização expansiva da economia encontrou terreno efetivo, sobretudo, após a crise financeira global de 2008, levando, inclusive, a modificações na divisão do trabalho em favor das cadeias globais de valor $(C G V)^{2}$. Os avanços recentes da microeletrônica (terceira revolução técnica) associaram, visceralmente, as TICs e a IA (Inteligência Artificial)para análise avançada e combinada de muitos dados, em tempo real, além de tecnologia física como robótica, drones, veículos autônomos e manufatura aditiva (impressão 3D) ${ }^{3}$. O declínio dos custos da infraestrutura básica, para

${ }^{2}$ Essa crise impulsionada pela ciranda do financiamento imobiliário norte-americano, inicialmente, decorreu do crescimento expressivo do capital fictício, a partir dos anos de 1990, com picos como o de 2007 em que os ativos financeiros chegaram a 376\% do PIB mundial (CHESNAIS, 2018), o que levou ao estouro da bolha em 2008, dada a discrepância com a produção da economia real, levando a que fosse injetado na economia recursos públicos (títulos da dívida pública), resguardando, da destruição, os capitais sem lastro de valor.

${ }^{3}$ De Stefano (2020) explica que a inteligência artificial é uma inteligência específica ou estreita, pois a inteligência geral só é possível, hoje, aos humanos que são capazes de inteligência complexa que envolve entender e raciocinar num contexto. A inteligência específica -Inteligência Artificial - é orientada para uma tarefa (jogar, prever o clima, sugerir programas ou vendas, por exemplo) e em alguns casos uma articulação de inteligências específicas, como os programas de tradução online ou os automotores. São fundamentais para desenvolver a Inteligência Artificial os algoritmos que são conjuntos de instruções (programação) voltadas para resolver um problema, a partir da entrada de dados e operações simples por máquinas computadorizadas. A disseminação dessa possibilidade tecnológica leva a que o automatismo passe a operar expansivamente nas diferentes áreas, fazendo coisas antes próprias apenas aos humanos. Os programadores de computação traduzem os problemas do mundo para 
esses meios e suportes, foi fundamental e bem expressivo, o que liberou em tempo real o acesso a grande volume de dados, suas análises preditivas e a viabilização de medidas para contrarrestar os custos do sistema produtivo.

Chesnais (2018) concorda com essa interpretação sublinhando que a mundialização do exército industrial de reserva sedimentou as estratégias transnacionais do capital em torno das CGVs, por meio de vasta rede de subcontratação que reposicionou os lucros das grandes corporações, viabilizando novo estágio de centralização de capitais. O capital fictício funcionou aí como forte investidor de recursos rápidos, que cobra a conta por meio da eficiência e da produtividade, com baixos custos. Os gestores de fundos de pensão e fundos financeiros entram na ciranda especulativa apostando no capital a ser apropriado e desse modo, como credores, impõem a disciplina dos custos produtivos e do trabalho exaustivo e remunerado abaixo dos custos de reprodução social, de hoje.

Para Marx (2008), o capital fictício se valoriza sem sair do mercado financeiro, através dos títulos que possibilitam apropriação virtual de mais-valor (atual e futuro), procedendo a incursão no território do capital funcionante. Como investimento em troca de juros e dividendos, os títulos são uma promessa, portanto, um recurso virtual que depende da dinamização da economia real em escala crescente. Depende da captação de trabalho excedente e da realização do valor na comercialização, considerando variados fatores como a conexão do mercado mundial, as tecnologias poupadoras de trabalho vivo, as condições de acesso a insumos e logísticas de transporte e comercialização ${ }^{4}$.

essas máquinas resolverem por meio de bilhões de operações por segundo, que é, de fato, uma velocidade inconcebível para a mente humana. No trabalho, as diferentes tarefas viram algoritmos e, assim, ele é automatizado. Excetuando-se ações criativas e relativas às emoções humanas, todas as demais são, hoje, passíveis de resolução maquínica. Por isso, esse alcance tecnológico é de porte devastador sobre o trabalho.

${ }^{4}$ Para Chesnais (2018) é importante considerar que, hoje, esse capital fictício é garantido pela reprodução contínua de dívida pública, da poupança dos sistemas de aposentadoria por capitalização (fundos de pensão) e dos fundos de aplicação das sobras de recursos não investidos das rendas dos mais abastados, além do socorro, quando necessário, dos bancos centrais, com a contraface da elevação da austeridade ampliando a fratura social, em termos de precarização do trabalho edas políticas sociais, bem como a pilhagem dos recursos ambientais. 
Com efeito, é a expressão máxima do fetichismo do dinheiro, $\mathrm{D}$ que aparece gerando $\mathrm{D}^{\prime}$, dinheiro engendrando dinheiro. A apropriação de riqueza abstrata é o fim último do capital, motivo de seus mecanismos, ampliadamente, postos em movimento. Esse fetiche autômato aparece como coisa dos mercados financeiros, como fluxos de dividendos e de juros, distantes da economia real. Mas, as ligações são outras, podendo ser compreendida no contexto da produção de valor, que especifica a forma social capitalista. Outrossim, segundo Chesnais (2018), as relações imperialistas e os instrumentos de transmutação dos salários em capital (capitalização das aposentadorias) mudam profundamente a dinâmica da relação com o capital funcionante, se comparado a do século XIX. A centralização de capital e a expropriação do fundo de consumo e de vida dos trabalhadores colocam na mesa uma enxurrada de recursos em busca de valorização na economia real, com direito de saques maiores que a capacidade sistêmica real, porque não se pode entregar mais do que se produz. Daí a maior propensão à formação das bolhas financeiras e aos episódios de crise; de modo que as soluções, desde 1970, escavam mais fundo os problemas sistêmicos.

Nesse sentido, é que podemos ver como o capital fictício aprofundou sua agenda para lidar com a desaceleração da produção de mais-valor ditando mecanismos como: 1) fusões e aquisições de empresas, provocando a centralização de capitais com a formação de oligopólios nos diferentes segmentos da economia; 2) desenvolvimento da parafernália da governança corporativa, de maximização do valor para o acionista, fidelizando os gestores que passam a ter como alvo a dinâmica do cassino dos preços das ações e do alto desempenho da empresa (produção e apropriação de mais-valor); 3) reestruturação da economia internacional por meio das cadeias globais de valor (CGV), potencializadas com as TICs que também são organizadas com a dominância de oligopólios e contando com investimentos especulativos. As TICs auxiliam as empresas a aumentarem a produção, a centralização e a apropriação de mais valor gerados nas empresas subcontratadas e dispersas em diferentes pontos do mundo. 
A nova divisão internacional do trabalho gravita em torno das empresas chaves nos fluxos comerciais e tecnológicas globais, que funcionam mundialmente - no sentido de que o espaço mundial é a totalidade explorada - e obedecem a uma lógica financeira de supremacia da criação de valor para o acionista, como previamente agendado com o credor. Isso significa que as CGVs reorganizam a economia mundial orientadas pela externalização de riscos - sobretudo, aos trabalhadores - e apropriação de ganhos como renda.

Nesse universo, conquistaram expressão as empresas de inovação para experimentação de novas formas de trabalho de baixo custo, onde emergiram formas, por exemplo, diferenciadas de trabaIho por demanda, just in time - projetos temporários que organizam novos negócios com custos e riscos compartilhados com os trabalhadores. Enfatiza Huws (2017) que esse é o modelo de negócios baseado na dominância financeira, estruturado em torno da redução de custos de produção e de transações comerciais, além da externalização dos riscos para terceiros e a apropriação de lucros como renda para ativos financeiros que financiam esses projetos. Esse quadro intensificou a competição entre grandes corporações, dinamizando a gestão do tempo e giro do capital, e, impulsionando o trabalho logístico de viabilização da aceleração da realização do valor.

A fabricação disso coube às startups, elaborando projetos experimentais visando expansão futura em escala. Nesse processo, lançam mão de força de trabalho qualificada com baixo custo e formulam projetos de rebaixamento do valor da força de trabalho em geral - renda por demanda de trabalho - seguindo a lógica financeirizada. Afinal, inovação no capitalismo significa nova forma de extrair maisvalor e, como sinaliza Fontes (2017), as startups começam como pequenos projetos que estudam e testam modos de promover expropriações secundárias (direitos trabalhistas) e localizar espaços geográficos mais adequados, que elevem a extração de valor para maior escala. Seguidamente vendem a ideia a investidores que apostam no retorno rentável de parcela do mais valor, particularmente a capitais concentrados que têm ampla capacidade de inverter recursos para transformar em capital. Essa forma de negócio é de capital centraliza- 
do e a mediação da plataforma digital tende a tornar as relações de trabalho obscuras.

A interação entre TICs, capital financeiro e capital funcionante, portanto, ampliou o alcance do controle do trabalho, articulando diferentes segmentos econômicos, a ponto de reforçar a indefinição de fronteiras entre os rígidos ramos econômicos (SERFATI, 1998). Por isso, as grandes corporações que dominam as cadeias não têm fábricas físicas, mas dispõem de recursos como marcas e patente, enquanto suas subcontratadas produzem as mercadorias, em diferentes pontos do mundo.

Para isso, as tecnologias digitais foram fundamentais para simplificar e padronizar as tarefas, possibilitando a crescente mobilidade da força de trabalho e o monitoramento algorítmico. Em conjunto isso propiciou logar o trabalho e o trabalhador instantaneamente, o que significou estruturar: a) modelo de trabalho taskificado (tarefas); b) plenamente registrado (gravado através de GPS, com captura das teclas do computador usado, acionamento de webcam e inclusão de avaliações de clientes; c) com processo de trabalho disciplinado e avaliado à distância, sendo medido finamente em sua produtividade; c) baseado em gestão por meio de plataformas digitais, em que os trabalhadores ficam conectados permanentemente, recebendo notificações.

As grandes corporações ganham novo movimento de crescimento espiral fazendo uso das vantagens do desenvolvimento desigual planetário, com dinâmico protagonismo de grandes varejistas e comerciantes no comando das cadeias globais, pressionando as fábricas por redução de custos, aumento da produtividade e diminuição do tempo de produção e circulação de mercadorias. As fábricas contratadas respondem pela execução do modelo de produção, design e marketing estabelecido pelas grandes corporações. A compra em escala, mantém as empresas produtoras sob comando curto, que, então, tiram suas margens de lucro, principalmente, da maior austeridade no comando da força de trabalho e das relações e condições de trabalho 5 .

${ }^{5}$ Chan et ali (2019) trata dessa questão ao analisar as rédeas curtas da Apple sobre a Foxconn que produz os aparelhos eletrônicos da norte-americana, na esteira do desenvolvimen- 
Essa mutação modificou o modo como se produz e distribui os produtos e serviços, provocando o encurtamento entre fornecedores de suprimentos e produção, eliminando redes de intermediação e vendas (conexão direta entre "ativos" e interessados no produto e serviços); derretimento dos serviços de suporte como os serviços financeiros ou verificadores de dados de perfil do comprador na medida em que as transações passam a ser digitais, portanto, instantâneas - just in time. Adicionalmente, houve alargamento dos serviços na estrutura da economia, tamanha a importância da captação de dados do processo produtivo e dos produtos, como também do processo de mercadorização dos serviços (ANTUNES, 2018) ${ }^{6}$.

to da economia chinesa no quadro dos últimos 40 anos, que tanto envolve inovação tecnológica quanto oferta de grande exército de força de trabalho sub-remunerado. Do ponto de vista desse estudo, a inovação, o design e o marketing da Apple são complementados pela rede de fornecedores espalhados pela Ásia. A Apple estabelece "preços, vigilância do proces so de produção no local de trabalho, cronometragem da entrega dos produtos, etc. [...] Foxconn, articula-se a sua habilidade para manter a flexibilidade" $(2020$, p.36). As consequências "na manufatura competitiva tem sido condições de trabalho coercitivas e relações de trabaIho litigiosas" (p. 37). Atuando com outras grandes empresas como Sony e Microsoft a Foxconn opera com várias fábricas em diferentes partes do mundo. Sendo a expressão do resultado da fragmentação da produção com as terceirizações como condição de intensificação da exploração de mais-valor.

${ }^{6}$ De acordo com o IED (2020), a complexidade dessa racionalização empresarial está sendo chamada, pelo capital, de movimento de servitização para representar essa mobilidade da transformação das manufaturas em empresas de soluções de produtos e serviço. Informa ainda, como impactos mais evidentes, a ampliação de capital nos processos de trabalho devido a automação, "Espera-se que até 2025 os robôs industriais afetem de 36 a 60 milhões de empregos em tempo integral equivalentes dos 355 milhões de trabalhadores industriais aplicáveis e aumentem a produtividade em $75 \%$ para cada emprego em tempo integral." (IED, 2020, p. 8). Ainda que essa prospecção seja mais um anseio político de ordenação, do que realidade concreta hoje, é possível ver que os suntuosos avanços tecnológicos proporcionam eliminação dos empregos e aceleração da produtividade daqueles empregos que restarem Vale dizer que o Fórum Econômico Mundial e a OCDE têm discutido o tema do avanço da digitalização em seus últimos encontros, ocupados com a ampliação da digitalização, com a destruição de capitais que ela provoca e com o encurtamento do emprego que pode trazer transtornos conflitivos e impactar o consumo de mercadorias. Daí que emerge uma atenção especial e a disputa no âmbito do próprio capital sobre a questão da renda básica e a ques tão fiscal, no sentido de taxar mais competitivamente a economia digital, ao passo que também difunde o espraiamento da digitalização. 


\section{Fabricação da Inovação}

De acordo com a UNCTAD (ONU, 2019) a disseminação da digitalização no mundo é expressiva, mostrando que esse fluxo de inovações acelerado conta, no entanto, com comando concentrado na medida em que a riqueza digital está centralizada nos EUA e na China, com os países da periferia localizados nas franjas dessa geopolítica, como são os casos de países da África e da América latina. Informa, então que $75 \%$ das patentes tecnológicas estão na China e nos EUA, $50 \%$ dos gastos globais com a Internet das Coisas (IoT), 75\% do mercado de computação em nuvem e $90 \%$ do valor de capitalização de mercado das 70 maiores empresas de plataformas digitais do mundo ${ }^{7}$. Os demais países participam dessa onda, principalmente, como usuários e consumidores, restando, sobretudo ao capitalismo dependente do sul global, a condição de fornecedores de dados brutos (commodities), sem capacidades domésticas de criação de valor nesse campo. A renda de monopólio é uma marca dessas inovações, proporcionado pela lei de patentes e pela agressividade do pioneirismo das grandes corporações empresariais na área.

As informações do relatório sobre a velocidade da conectividade virtual desenham um quadro de forte disseminação dessas mudanças, pois a evolução do tráfego global da internet (Gigabytes por segundo), em 20 anos, apresenta forte dinamismo: 2002, consumo de 100GB; 2007, 2.000GB; 2017, 46.000GB; e, para 2022, a expectativa é de consumo de 150.700GB (ONU, 2019). Esse volume demonstra a impactante ampliação dos usuários da internet, das tecnologias de IA, da computação em nuvem, da automação, entre outras.

A ONU (2019) vê as plataformas como um negócio mais estratégico ainda porque elas atuam na economia como intermediárias e como infraestrutura, registrando e extraindo dados sobre ações, interações e transações online dos usuários. Para dimensionar isso, infor-

\footnotetext{
${ }^{7}$ Internet das coisas (IoT-Internet of Things) é um termo nomeia a onda de conexão das coisas do dia a dia à rede mundial de computadores, fazendo com que eletrodomésticos, meios de transporte e até mesmo tênis, roupas e maçanetas sejam conectadas à Internet e a outros dispositivos, como computadores e smartphones. A computação em nuvem envolve o acesso remoto e trabalho em tempo real, por meio da Internet, a arquivos, banco de dados e inteligência artificial, em escala global.
} 
ma que $40 \%$ das 20 maiores empresas por capitalização de mercado têm negócio baseado em plataformas e as grandes corporações monopolizam dois terços do valor total de mercado das 70 principais plataformas. As superplataformas são as superconhecidas: Microsoft, Apple, Amazon, Google, Facebook, Tencent e Alibaba. O desempenho financeiro dessa área é espetaculoso e o conjunto de todas essas plataformas empresas somou, em 2017, sete trilhões de dólares.

Além dessa dinâmica econômica monopolizada mais geral, essas grandes corporações atuam também como gigantes no seu core específico: Google tem $90 \%$ do mercado de buscas na internet; Facebook tem dois terços do mercado global de mídia social, sendo a plataforma a principal em $90 \%$ do mundo. O relatório mostra que a China também domina um pedaço considerável, pois mantém a WeChat com 1 bilhão de usuários e seu instrumento de pagamento online é dominante no conjunto do mercado; além disso Alibaba tem $60 \%$ do comércio eletrônico chinês. Por outro lado, o crescimento desses monopólios avança em direção a aquisição de empresas menores e em diversificações de negócios, chegando a ter parceria com indústrias tradicionais em setores como o automotivo, o de semicondutores e o de varejo (ONU, 2019).

O Brasil aparece como uma liderança importante no consumo, com o uso das redes sociais, estando em segundo lugar entre os usuários de Whatsapp no mundo; segundo lugar no uso de Instagram; terceiro no uso de Facebook; terceiro em Linkedin; segundo em Waze; segundo em Pinterest (MACKINSEY, 2019). No entanto, em termos de e-commerce responde por apenas 6\%, enquanto China e EUA, respectivamente, por $20 \%$ e $12 \%$. Mas, os aparelhos do capital vêm esse dado com chances de alteração, pois há uma dinâmica acelerada de crescimento de startups, somando mais de 10.000 , sendo $40 \%$ em menos de 2 anos. Outro dado importante é sobre o sistema financeiro, pois mais da metade da população brasileira são de usuários de serviços bancários e $58 \%$ de todas as transações financeiras estão online. Ainda nesse campo, chama a atenção dos investidores a existência de 400 startups de tecnologia financeira e 7 milhões de clientes em bancos apenas digitais.- "múltiplas empresas, muitas delas de risco e startups que exploram a inovação pela inovação. A cultura 
capitalista se tornou obcecada pelo poder da inovação. [...] um objeto de fetiche do desejo capitalista" (HARVEY, 2016, p.96).

Desse quadro geral de incentivo à digitalização é possível destacar que, entre 2015 e 2020, há uma nova etapa de seu aprofundamento com a expansão da IA não apenas servindo para indexar informações, mas para formular um juízo especializado sobre tema objetivo da vida. Tomando à frente da nossa consciência prática, em tempo real, sobre inúmeras variáveis, para escolher o melhor deslocamento urbano, um programa de dieta, uma listagem de livros ou uma programação de férias, além de uma plêiade de sistemas automatizados e inteligentes para organização e gestão das empresas. $\mathrm{O}$ argumento técnico especializado sobre amplos aspectos da realidade e em tempo real provoca a expressiva legitimidade social da IA, com repercussão massiva, sobretudo, a partir dos smartphones e aplicativos. $\mathrm{O}$ melhor exemplo disse é o assistente virtual doméstico ou pessoal, como o Alexa da Amazon ${ }^{8}$.

Zuboff (2018) é decisiva ao mostrar que essas grandes corporações tecnológicas, mundializadas, atuam em favor da aceleração do giro do capital, com a transformação da informação trivial em material para publicidade, por exemplo. Esse é o métier principal da Google que com a catalogação, armazenagem e análise de dados veicula publicidade, monetizando as informações numa "nova arquitetura glo-

\footnotetext{
${ }^{8}$ Paralelamente, difundiu o consenso de que não há problemas que não possam ser equacionados pelas TICs ou pela IA, por isso o propósito é a disrupção de velhas práticas empresari ais e governamentais, como também dos costumes cotidianos da vida privada, por meio dos recursos digitais. $\mathrm{O}$ que em si é o aperfeiçoamento da reificação, destinando às coisas a pre ponderância sobre as relações sociais. O desenvolvimento tecnológico sob a órbita da forma social do valor impõe particularidades. A inovação digital difundida por meio da Inteligência Artificial tem sido a base de projetos empresariais de indução de comportamentos de alimentação, leitura, afetividade, transporte, lazer, educação, saúde, finanças, entre outros, que a rigor induziram a ampliação da mercadorização da vida, que além de negócios se fez como uma dimensão política muito relevante. Trata-se não apenas de uma incorporação tecnológica às práticas sociais, mas um modo naturalizado de ver as coisas como "boas para todos" - porque otimiza tempo e processos sociais, aquilo que Sardin chama de ideologia dos startups (2018). É interessante, arrolar aqui que, segundo o IBGE, em 2018, 93,2\% de todas as residências brasileiras possuíam celular e79,1\% dos indivíduos maiores de 10 anos contavam com aparelho celular para uso pessoal. A Pnad Contínua verificou ainda que $70,1 \%$ dos domicílios usavam a internet, o que significa 8 em cada 10 domicílios (IBGE, 2020). Ainda que a qualidade da conectividade e dos aparelhos não sejam iguais é correto pensar que a sociedade brasileira está sendo paulatinamente digitalizada.
} 
bal de captura e análise de dados que produz recompensas e punições destinadas a modificar e transformar em mercadoria o comportamento visando à obtenção de lucro." (2018, p. 57) ${ }^{9}$

De maneira que ganha novo impulso a mercadorização, envolvendo a venda de espaço e de tempo para "influenciar comportamentos para obter lucro (e) daqueles que compram tais oportunidades" (ZUBOFF, 2018, p. 58). E isso é feito por meio da coleta, catalogação, análise e conexão de dados em poder das grandes corporações de TICs, visando atuar sobre comportamentos e desse modo potencializar a comercialização com informações da cotidianidade ao transformar a mesma em texto eletrônico, no volumoso Big Data ${ }^{10}$ "todos os cliques [...] são adquiridos, tornados abstratos, agregados, analisados, embalados, vendidos, analisados mais e mais e vendidos novamente." (ZUBOFF, 2018, p. 31-32).

Enfim, além de escoar mercadoria vendendo produtos como aparelhos computadorizados de diferentes portes, acessórios e softwares, essas tecnologias provocaram uma reviravolta no consumo produtivo e individual, criando vitrines customizadas com base nos perfis elaborados pelos algoritmos.

Desde Marx, sabemos que a mobilidade do produto até o mercado deve ser entendida como parte do processo de produção do mais-valor, por isso a atenção ao papel das ferrovias e dos navios, na sua época. No entanto, levar a informação sobre o produto também pode ser considerado um meio como a telefonia, a radiodifusão e ou-

\footnotetext{
${ }^{9}$ A ponto de impactar as empresas jornalísticas ao virarem verdadeiras máquinas personalizadas de publicidade, baseadas nos perfis customizados dos algoritmos. Essas grandes corporações abriram um canal de amplo escoamento da publicidade, além de estarem modificando a relação com a informação e com o entretenimento, o que também impacta os capitais tradicionais do audiovisual. Mesmo que essas empresas TICs absorvam conteúdo jornalístico o modus operandi não se assemelha ao trabalho jornalístico tradicional qualificado e o salário tende a ser residual. De certo modo, o ajuste dessas empresas tradicionais tem sido por meio do trabalho por projeto (CNPJ)e pela incorporação do leitor e telespectador na produção de imagens e pesquisa de furos jornalísticos, descaracterizando antigas ocupações nesse ramo. Além disso, demonstram uma reorganização em direção a modelos empresariais de plataformas, com programas acessados sobre demanda.

${ }^{10}$ Como se sabe, o Big Data é um substancial catálogo, com armazenamento e fluxo de dados, ininterrupto e exponencial, que lida com informações de conversas, compras e navegação na internet, assim como de câmeras, geolocalização, relógios, braceletes e outros apareIhos conectados.
} 
tras indústrias midiáticas que, no século $X X$, estimularam o consumo. As TICs promovem novo impulso nesse propósito, inclusive customizando a mobilização de perfis mais exatos de consumidores para a publicidade, flexibilizando o marketing. Isso tem importância porque a redução do tempo de realização do ciclo completo do capital é uma busca constante na medida em que assim se realiza de fato o maisvalor. Entre os fatores favoráveis a isso, Marx mencionava os meios de transporte e os de comunicação que não produzem nova mercadoria, mas o valor de uso desse elo da cadeia é transportar e comunicar as mercadorias ao mercado. E essa é uma dimensão importante das novas tecnologias engendradas pela microeletrônica, em especial, também, porque colocam em novo patamar a aceleração do tempo, a aproximação dos espaços e o enxugamento das ações - tanto em termos de trabalho quanto de consumo (produtivo e dos indivíduos) $)^{11}$.

Sinteticamente, vemos emergir uma interação algorítmica com o cotidiano da vida social, transformando esses dispositivos digitais em parte da cesta de consumo das necessidades sociais, de maneira que a interação com essas tecnologias passa a ser compulsória. A exigência dessa mediação para acesso a serviços públicos e privados, como tendência mundial, impulsiona a aquisição de equipamentos fixos ou móveis, além de serviço de banda larga "e, mais que tudo, a aderir às regras unilaterais e extorsivas das plataformas sociodigitais. [...] em troca de serviços aparentemente gratuitos ou muito baratos, o usuário está obrigado a abrir mão de sua privacidade." (DANTAS e RAULINO, 2020, p. 133). Assim, as corporações reduzem o

\footnotetext{
${ }^{11}$ Dantas e Raulino (2020) nos mostram que o vendedor remunera a plataforma: i) se seu anúncio é visualizado por algum tempo em alguma das milhares de telas; ii) se seu anúncio é "clicado" por alguém, abrindo-se por conseguinte, na tela de quem clicou nele o seu sítio; iii) pelo tempo de permanência, no sítio, do (s) autor (es) desse "click"; IV) pela efetiva consecu ção de algum negócio; iv) ou ainda, por outros fatores[...]" (2020, p. 131). Os autores, ao estudarem o ciclo de acumulação de capital a partir do Facebook e do Youtube, afirmaram que o capitalismo atual se organiza em variadas plataformas digitais de mercado, que conformam a seguinte tipologia: "1) Aquelas remuneradas por publicidade, logo dependentes da produção de audiência, exato caso do Facebook, do Youtube e ainda de outras; 2)aquelas se destinam a aproximar diretamente compradores e vendedores (como Amazon); 3) aquelas que facilitam a intermediação financeira (como Paypal)." (2020, p. 126)
} 
tempo de rotação do capital e programam comportamentos de propensão ao consumo ${ }^{12}$.

Ainda que seja parte da dinâmica maior da flexibilização que mencionamos antes, a plataformização do trabalho tem especificidade e só alcança expansão no rastro da crise das hipotecas norte-americanas de 2008, que de um lado mobilizou as empresas a conterem os custos, levando a que as plataformas ganhassem terreno ${ }^{13}$, e, por outro, se converteu num escoadouro de investimento do capital financeiro protegido da destruição pelos bancos centrais que injetaram volumosos recursos (CHESNAIS, 2018). Essa tendência atinge o Brasil a partir de 2015 - no encalço das duras consequências do estouro da bolha das finanças -, tendo impulso maior com a reforma trabalhista de $2017^{14}$ ${ }^{12}$ Vale registrar que os dados pessoais são chaves hoje porque com eles se estabelecem per-
fis e isso tem grande interesse econômico porque possibilita publicidade customizada, mobi-
lizando desejos em pessoas específicas, com potencialidades de atração. Permite também a
manipulação política sobre comportamentos assim como adulteração, como tem ocorrido
com as chamadas fakenews, com destaque às eleições e à dinâmica política digital no Brasil,
nos EUA e na própria campanha do Brexit na Inglaterra (CALDAS e CALDAS, 2019). O debate
jurídico sobre isso está em ascensão, inclusive, no Brasil, mas ainda é uma incógnita se será
possível regular efetivamente o uso desses dados que circulam nos dispositivos digitais e em
que extensão, dada a especificidade da tecnologia em si. A lei geral de proteção de
dados,13.709/ 2018, entrou em vigor em agosto último, na esteira da regulação europeia de
2016 . É difícil ainda prever o alcance desta regulação e as consequências das margens da li-
beralização desses dispositivos, mas seguirá com fios invisíveis de reprodução ampliada do
capital, conforme estamos abordando.

${ }^{13}$ Efetivamente, outros dois episódios do quadro da reestruturação do capital podem ser su blinhados aqui, a respeito da digitalização da economia. Um evento marcante foi a crise da bolha da internet ou bolha ponto com, entre os anos de 1994 e 2000. A alta das ações das empresas TICs - no contexto da popularização da internet e do forte subsídio do Estado norte-americano ao setor - não tinha conexão com a realidade concreta da contabilidade empresarial, atingindo em março de 2000 hiperelevação com 5000 pontos no índice Nasdaq (bolsa de valores das empresas de tecnologia), despencando depois (para cerca de 2000 pontos) e empurrando a economia norte-americana e mundial para forte recessão com falência de empresas e desemprego (BRENNER, 2002). A especulação sobre lucros futuros em contexto de inovação tecnológica chegou a níveis elevadíssimos sem que existisse receita correspondente, de modo que a realidade se impôs ao estourar a bolha. Outro evento importante, ainda nos anos de 1990, foi a privatização neoliberal das telecomunicações porque criou as condições da expansão digital.

${ }^{14}$ Consideramos pertinente registrar aqui também a pandemia do coronavírus (2019/2020) que exigiu isolamento social e levou à expansão das plataformas no trabalho, na educação, na saúde e no consumo em geral. Vale dizer que, em verdade, a pandemia colocou a nu os limites sociais da heterogeneidade das relações de trabalho (históricas e atuais) e da baixa 


\title{
Trabalho nas Plataformas Digitais ou as Plataformas Digi- tais no Trabalho
}

\author{
No campo jurídico do trabalho desenvolve-se um amplo deba- \\ te sobre verdadeiras e falsas plataformas, em razão de algumas delas \\ apresentarem-se publicamente como intermediadoras ou como \\ mero comércio (CARELLI et al, 2020) ${ }^{15}$. A razão instrumental descreve \\ a plataforma digital como um dispositivo tecnológico que expressa \\ um novo estágio das TICs e da IA ao colocar em rede de conexão inte-
}

renda do trabalho, pois se mostraram grandes empecilhos para o aceite do isolamento social recomendado pela Organização Mundial da Saúde ou para cobrir as despesas de subsistência mínima de alimentação e higiene, com a queda do intercâmbio econômico. Como se sabe a Covid-19 (sigla para a terminologia inglesa Coronavírus Disease 2019) é uma doença infecciosa sistêmica provocada pelo coronavírus (SARS-Cov-2), com alto poder de disseminação e que foi diagnosticada em humanos na cidade de Wuhan (China) em dezembro de 2019, mas os estudos avançam no sentido de melhor delimitar a história epidemiológica da doença e a atuação do vírus no organismo humano. Mas, como afirma Chesnais é uma crise sanitária que está se desdobrando dentro da recessão econômica e da crise estrutural do capital: "Na realidade, a grande recessão iniciada há doze anos nunca terminou. Mesmo que as convenções estatísticas digam que, nos Estados Unidos, a recessão iniciada em dezembro de 2007 tenha terminado em junho de 2009, os economistas de língua inglesa designam pelo nome de Great Depression (grande depressão), o período aberto pela crise mundial, em que a falência, em outubro de 2008, do banco Lehmann Brothers foi o ponto culminante. Esse nome é totalmente justificado pela nitidez da ruptura com o período que o precedeu e, mais fundamentalmente, pela fase, bastante longa, de crescimento iniciada no final da década de 1940. O gráfico mostra que o crescimento desacelerou progressivamente, caindo a um ponto muito baixo em 1974-1975 e 1979-1982, mas somente em 2008-2009, ele foi verdadeiramente interrompido" (2020, s/p). Isso é importante para entender que já existia uma dura crise em curso, conforme também ressaltou Michel Roberts ao demonstrar dados do Fundo Monetário Internacional em que o ano de 2019 é apresentado como o de queda do crescimento global, comparado com os dez anos anteriores. O crescimento da zona do euro ficou $11 \%$ abaixo da média de 10 anos; o G7 e as economias avançadas tiveram um desempenho ainda mais baixo; a taxa de crescimento dos mercados emergentes foi $27 \%$ menor; a taxa de crescimento global, em 2019 , foi $23 \%$ menor que a média desde o final do Grande recessão. [...]. Portanto, a economia capitalista mundial já estava entrando em recessão (muito atrasada em relação às expectativas) antes da chegada da pandemia de coronavírus" (2020, s/p). A superposição dessas duas dinâmicas críticas trouxe desdobramentos nefastos para o trabalho, a proteção legal para o isolamento e a destinação de renda aos que vivem do fluxo de atividades como os trabalhadores informais e desempregados.

${ }^{15}$ Como é o caso da Uber que diz não ter carros e, por isso, não é uma empresa prestadora de serviços. Mas, o caso é questionado em muitos tribunais pelo mundo, existindo ganhos de causa para trabalhadores e exigência de reconhecimento da forma emprego, no entanto, a contestação segue como prática da empresa nos fóruns judiciais (Cf. CARELLI et ali, 2020). 
rativa, em tempo real, diferentes agentes interessados em lazer, trabalho, serviços e comércios variados ${ }^{16}$. Depende de uma sociabilidade informatizada, de infraestrutura de tecnologia potente para suportar a interação de dados e de baixo custo em relação a outros meios, além de se basear em feedbacks contínuos entre os usuários sobre as operações.

A expansão dessa forma de trabalho, commediação digital, nomeamos aqui de dinâmica de plataformização do trabalho que, sinteticamente, consiste na expansão do uso das plataformas digitais para realização do trabalho, cujo primeiro efeito é a precarização e o mascaramento das relações de trabalho ${ }^{17}$.

As experiências laborativas impactadas pelas TICs e IA conformam um universo amplo de formas de trabalho, envolvendo novas e antigas ocupações.

\section{Trabalho com Mediação Digital}

1) o trabalho de desenvolvimento de software

2) o trabalho de montagem de hardware e similares nas fábricas

3) o trabalho de telemarketing ou call centers

4) o trabalho diretamente em plataformas digitais ${ }^{18}$;

5) o trabalho convencional transformado com a interface de dados e a comunicação remota ${ }^{19}$.

\footnotetext{
${ }^{16}$ Como se sabe, as plataformas mais conhecidas, mundialmente, são as empresas Google e Facebook que mobilizam difusão de mídia por meio de seus serviços de informação e redes sociais; o AirBnB que articula proprietários de casas com turistas para hospedagem; a Uber que conecta motoristas de carros com passageiros, market places como Amazon, Alibaba, eBay, que conectam varejistas e compradores; além, do PlayStation e XBox que conectam plataformas de games online, como Zynga e Blizzard a jogadores. Além dessas corporações globalizadas, de alcance local, no Brasil e na América Latina, temos o Mercado Livre e Magalu, no ramo da intermediação de mercadorias, e, o Rappi e o iFood como delivery.

${ }^{17}$ Estudos importantes sobre essa realidade do trabalho contemporâneo nomeiam o fenômeno como uberização, em alusão a empresa pioneira na adoção desse tipo de negócio e de precarização do trabalho. Grossman (2020), por outro lado, considera que a plataformização é mais adequada porque permite considerar outras práticas empresariais. Desenvolvemos a hipótese de que a plataformização permite avançar na compreensão da plataforma nos novos trabalhos e naqueles institucionalizados, para perceber a amplitude da gestão digital do trabalho.

${ }^{18}$ Trata-se de trabalho intermediado ou a serviço de plataformas empresas, nas áreas de transporte, alimentação, limpeza doméstica, serviços para cães e outros animais, market pla$c e$, cuidados pessoais, jornalismo, serviços de tradução e correção de textos, serviços de saúde, trabalhadores de restaurantes e eventos, entre outros.
} 
A apreciação mais miúda desta caracterização mostra que o processo de plataformização do trabalho envolve a extinção de antigos postos de trabalho, a mediação das TICs nas ocupações tradicionais e a emersão de ocupações novas, promovendo uma série de alteridades nos processos e mercados de trabalho. Sendo tendência comum impulsionada pela dinâmica do trabalho social médio do capitalismo hoje, a precarização - genericamente identificada pelas variáveis: incerteza de atividade laboral estável; baixa renda; longas jornadas e ausência de proteção social ${ }^{20}$. De modo que essa mudança tecnológica de gestão aprofunda a transferência de risco para os trabalhadores, em termos de renda, saúde e segurança social (ABÍLIO, 2019, 2020; LIMA e BRIDI, 2019; GARCIA, 2020), direcionando mais fundo de consumo e de vida da classe trabalhadora para o mais valor. "O tempo de trabalho como medida de valor impõe a riqueza baseada na pobreza, e o tempo disponível existe através e devido à sua antítese ao tempo de trabalho excedente [...]" (MARX, 2011, p. 709). Isso implica para Marx entender "a imposição de todo o tempo do indivíduo como tempo de trabalho, e sua degradação, portanto, a

\footnotetext{
${ }^{19}$ Não é demais destacar que aparelhos de formação de consenso sobre as estratégias do capital, como o Fórum Econômico Mundial, a Organização Internacional do Trabalho e a Confederação Nacional do Trabalho(CNI-Brasil) têm realizado estudos sobre a transição laboral com a expansão das tecnologias, apontando para a ampliação do processo de digitalização na economia como fator de forte impacto sobre o trabalho.

${ }^{20} \mathrm{~A}$ problemática da precarização nem sempre é claramente definida nos estudos, por isso consideramos pertinente dizer que entendemos a precarização do trabalho como dinâmica de dominação social para exploração da força de trabalho, apoiada na depreciação das condições e relações de trabalho no tocante, em especial: a) contratação por variadas formas (direta e indiretamente), tendência ao encobrimento da relação de emprego e volatilidade dos trabalhadores nos postos; b) remuneração reduzida ou orientada pelo desempenho; c) jornadas de trabalho extensas, flexibilização de horários, despadronização de horários e invisibilidade das horas extras; d) dilapidação da saúde do trabalhador pela exaustão, pelos acidentes e doenças ocupacionais; e) enfraquecimento das relações coletivas na dinâmica do processo de trabalho e da ação dos sindicatos; f) enfraquecimento da proteção social previdenciária. É um conceito relacional porque se refere à impossibilidade histórica da segurança e estabilidade da venda da força de trabalho numa forma social específica em que a vida social depende do trabalho. Portanto, essas tendências conformam a disseminação da quebra dos vínculos estáveis nas relações de trabalho que haviam sido conquistados e do trabalho informal, historicamente relevante no capitalismo dependente, e seus novos desdobramentos (DRUCK, 2013).
} 
mero trabalhador, subordinação através do trabalho" (MARX, 2011, p. 709)

Todavia, além dessa tendência geral da mediação digital e da precarização, esses trabalhos não se explicam por eles mesmos. A complexidade da divisão do trabalho hoje exige que o estudo do trabalho considere a cadeia produtiva globalmente, como variadas práticas laborativas, ramos econômicos e de gestão empresarial que se conectam por elos técnicos e espaciais. Isso exige que categorias teóricas sejam pensadas articuladamente de modo a captar a universalidade do trabalho que se fragmenta, como parte da geleia de trabalho abstrato (substância do valor). Antigas cisões entre trabalhos manuais e trabalhos não manuais são desmanchadas e reconstituídas de outro modo, assim como a segmentação das esferas da produção, da distribuição e do consumo se dissolvem, além de parte do trabaIho com a automação também se transformar em atividade dos usuários dos serviços. Ou mesmo, trabalhos altamente qualificados no campo das TICs dependam de trabalhos socialmente e ambientalmente predatórios da extração de minérios e produção de energia (HUWS, 2018; ANTUNES, 2020). O estudo do trabalho mais do que nunca exige a recomposição dos elos perdidos, submersos na cadeia de valor globalizada (CHESNAIS, 2018).

Para isso, é elucidativo pensar a nova configuração coletiva do trabalho como trabalho capitalista mesmo, sob condições reconfiguradas. Ou seja, a partir da teoria do valor para, assim, compreender que o fenômeno das TICs e da IA fundamenta-se nas categorias marxianas de valor, mais-valor e lucro como determinantes da lógica essencialmente expansiva do capital. Isso está condensado na mercadoria que é a forma primária de mediação social da sociabilidade capitalista e a tecnologia como a adição de produtividade que é, ou seja, como condição da produção de riqueza na forma valor. Esse é o caminho para pensar as práticas sociais atravessadas pelas novas tecnologias, recompondo suas raízes com o todo social.

O trabalho com mediação digital não está fora desta base fundamental da forma social capitalista, nem expressa a extinção dos trabalhos manuais, sobretudo, porque o cabeamento da sociedade não seria possível sem larga infraestrutura,"Sem a produção de ener- 
gia, cabos satélites, computadores, switches, telefones celulares e miIhares de outros produtos materiais [...]." (HUWS, 2017, p. 329). Os trabalhos estão distribuídos em pontas das cadeias globais de valor, envolvendo tanto extrativismo predatório de metais como também de manufatura de peças e equipamentos, ainda que economia digital apareça com o invólucro de coisa à parte, com dinamismo próprio e descolado dos demais elos da cadeia. Mas, isso é apenas a superfície das coisas. Essa tendência é uma forma de mistificar o trabalho intangível das TICs e disseminar o fetiche das tecnologias que se reproduzem no cotidiano como sujeito-coisa, com força superior às relações sociais. Inclusive porque, no reino das TICS e da IA, há também trabalho intangível que é de baixa qualificação e mal remunerado, tais quais outras dinâmicas da economia capitalista, do que são exemplos as modalidades crowdwork e microtrabalhos (OIT, 2020).

Isso não significa desconsiderar as propriedades e a dimensão das mudanças tecnológicas ou mesmo seus efeitos destruindo postos de trabalho na forma emprego (de maior qualidade), mas compreendê-las como reprodução ampliada do capital e, portanto, a partir de suas categorias fundamentais.

As grandes corporações como Google e Facebook vendem publicidade contando com a audiência dos usuários das redes, com isso participam no processo de comercialização das mercadorias que são vendidas em publicidade customizada, apresentando vantagens comparativas para o capitalista que tem posse de mais-valor em mercadorias. Ainda que também incorpore trabalho sob as condições de coação do trabalho capitalista em geral, configurando parte do trabaIho abstrato, a transação com as empresas TICs é sobre parcela domais valor produzido pelas empresas anunciadas ${ }^{21}$.

Por outro lado, nas plataformas de comércio online como a Amazon ou o Mercado Livre, comercializam mercadorias e por isso

\footnotetext{
${ }^{21} \hat{E}$ disso que vive, também, as investidoras financeiras dessas grandes corporações, ou seja de renda. Também, os aplicativos que cobram taxas dos usuários para acessar informações ou serviços como sites de música, banco de pesquisas, vídeos, livros, jogos e software online. Como também sites de agenciamento de emprego, cotação de tarifas de viagens e o Airbnb. "Seja qual for a mistura de fontes de receita, a maior parte do lucro de tais empresas provém de alguma combinação de cobrança por uso ou de comissões de fornecedores de serviços e/ou usuários de serviços e/ou anunciantes - em outras palavras, renda" (HUWS, 2017, p. 337)
} 
não produzem mais valor, mas capturam parcela do valor dos produtores das mercadorias. A escala de comercialização para muitas é de tal porte que toda uma estruturação baseada na aceleração do tempo torna mais complexa a empreitada, do que aquela do comércio tradicional. Aliás, a Amazon, e, outras plataformas empresas voltadas para entrega rápida, contam com os algoritmos, o trabalho taylorizado e o trabalho bico (biscate) de entregadores como centrais nessa aceleração do tempo e apropriação célere de parcela do valor (DELFANTI, 2019).

Com efeito, o avanço da digitalização, sobre os processos produtivos e de serviços, dificulta separar o que é genuinamente a economia digital e as demais dinâmicas econômicas, sobretudo quando os variados ramos se conectam em cadeias globais, derretendo fronteiras delineadas. A modernização das ferramentas do trabalho, hoje, tem forte apoio no trabalho digital seja como operação de instrumentos de comando digital, atualização de software, elaboração de produtos imateriais ou ainda como capacitação de trabalhadores sobre trabalhos dessa natureza. Anteriormente, as atividades de serviços variados, de dentro de uma empresa, eram melhores distinguíveis, inclusive dos trabalhos administrativos, mas hoje todas as funções recebem algum dispositivo online e variadas TICs - "em suma, toda a cadeia de valor do portão da fábrica (ou do local de desenvolvimento de software) ao consumidor final deve ser considerada como trabalho produtivo" (HUWS, 2017, p. 343)

Por esse ângulo, é que a cadeia precisa ser o foco de análise do estudo do trabalho digital, evidenciando a variedade de trabalhos e as formas de contrato e de uso da força de trabalho. É o caso de pensarmos que a produção dos aparelhos portáteis (smartphones e tablets) resultam de "trabalho de mineiros, operários de linha de montagem, trabalhadores químicos, designers, engenheiros, trabaIhadores de teleatendimento, trabalhadores de escritório, faxineiro e muitos outros" (HUWS, 2017, p. 358), atuantes em diferentes elos e geografias globais da cadeia produtiva.

Em síntese, o expansionismo do capital impõe desenvolvimento tecnológico tanto para produzir novas mercadorias como para simplificar o processo de produção com o objetivo de reduzir o custo do 
trabalho, a interação entre essas duas abas leva a uma cadeia cada vez mais elaborada e polarizada em variadas relações de trabalho. Estas cadeias são extensas, com subcontratações e com espraiamento espacial ao redor do mundo. Esta divisão do trabalho não se aplica só a processos manuais, mas também a processos imateriais, e, todos os trabalhadores estão indelevelmente vinculados um ao outro pela lógica do capital, com posições complementares, ainda que não saibam.

Todavia, isso não significa que não possamos delimitar a particularidade do trabalho plataformizado como totalidade espacial (ANTUNES, 2020; HUWS, 2020), apenas esse não é nosso objeto no presente texto, em que escolhemos demonstrar a aproximação dos trabalhos pelas inovações da gestão do trabalho, seja pelo controle oportunizado pelos algoritmos, seja pela precarização do trabalho. Vejamos que contribuição esse movimento analítico pode ainda nos trazer.

O dimensionamento da plataformização no mercado de trabaIho é ainda limitado, e incerto porque os órgãos oficiais e tradicionais de pesquisa não analisam essa variável ${ }^{22}$. Muito terá que ser feito para definir aportes metodológicos adequados e condições estruturais para realizar investigações dessa estatura. Tudo indica que para entender o mercado de trabalho, daqui em diante, será preciso lidar com informações efetivas desta realidade, na medida em que o cenário, tendencialmente, é de expansão desse fenômeno, a exemplo do que já ocorre na Europa e nos EUA (HUWS et al, 2019).

$\mathrm{Na}$ realidade concreta, o trabalho em plataforma empresa emerge não só pela inovação científica, mas pelo conjunto de condicionalidades sociais e para verificá-las é importante considerar os aspectos comuns desses trabalhos mediados pelas plataformas, hoje, especialmente marcados pela depredação das condições de vida e

\footnotetext{
${ }^{22}$ De acordo com GRAVAS (2019) aplicativos de serviços de transportes e entregas de alimentos e outros serviços como Uber, Cabify, 99, iFoof, Rappi são o principal empregador do país se tomados em conjunto, e, que de acordo com o Instituto Locomotiva seria da ordem de quase 4 milhões de trabalhadores, somente nesse tipo de plataforma. Garcia (2020) diz que esse dado ainda é incerto e sua pesquisa, não concluída aponta para existência de 3 miIhões de trabalhadores, com base nos dados da PNAD/IBGE. Mas, isso se limita às plataformas de transporte e delivery, portanto, reúne os principais sem abarcar o conjunto das formasplataformizadas de trabalho.
} 
trabalho de seus trabalhadores(ABÍLIO, 2019, 2020; LIMA e BRIDI, 2019).

\section{Características dos Trabalhos das Plataformas Empresas}

a) atração de desempregados e subempregados, ou seja, trabalhadores em situação de ausência de renda ou com renda rebaixada para atender às necessidades sociais de recomposição da força de trabalho.

b) longas jornadas de trabalho, a ponto de interferir negativamente no tempo para cuidados pessoais, descanso, necessidades fisiológicas e relações afetivas.

c) responsabilização do trabalhador pelos custos e riscos do trabalho.

d) vinculação dos rendimentos ao desempenho de cada um, em cada dia ou tarefa, em termos quantitativos e de avaliação positiva do usuário da plataforma contratante (sistema de reputação).

e) dinâmica de trabalho de forte concorrência entre os trabalhadores em razão do número alto de trabalhadores expurgados para o desemprego.

f) simulacro da relação de emprego, com os trabalhadores sendo tratados como "parceiros", descaracterizando a condição de empregador da empresa plataforma.

g) derretimento da forma jurídica do emprego e dinamização da gestão eficiente do trabalho por meio da funcionalidade dos algoritmos.

Ainda que envolto em narrativa de inovação técnica, é a precarização e o desemprego que podem localizar os fortes condicionantes da expansão das ocupações plataformizadas. No sentido de que a insegurança quanto às condições de reprodução social, próprias do desemprego e do subemprego, materializa a funcionalidade da superpopulação relativa criando o ambiente favorável ao envolvimento com competências para lidar com essas tecnologias, e, instrumentalizam uma subjetivação marcada pelo modo de vida empreendedor e flexível, baseado em relações de trabalho individualizadas e dependentes da produtividade e da avaliação comportamental ${ }^{23}$.

\footnotetext{
${ }^{23}$ Durante esses quarenta anos de mudanças no trabalho, despontou na narrativa neoliberal a defesa do empreendedorismo como ideologia e como materialização de alternativa ao de semprego. Consiste em estratégia capitalista para mobilizar a externalização produtiva por meio do fortalecimento de trabalho informal ou autônomo sem a regulação pública de emprego, reduzindo custos produtivos e embaçando a subordinação com a empresa. Com efeito, é estratégia de geração de trabalho sem a relação formal de emprego para viabilizar o processo global de produção e reprodução social encobrindo a subsunção efetiva do trabaIho ao capital. A subordinação é transformada retoricamente em autonomia, como forma de barganhar a mercadoria força de trabalho como se, supostamente, fosse uma empresa. A autonomia e o anseio pela mobilidade social formam os requisitos subjetivos manipulados nas narrativas, tendo por base a mobilização do individualismo, do alto desempenho da
} 
Em suma, essas experiências laborativas de um modo ou de outro estão transformando o mundo do trabalho, na medida em que a comunicação por satélite e a inteligência artificial aprofundam a compressão espaço-tempo com a diminuição das atividades do processo de trabalho e a instantaneidade das ações, enxugando o corpo laboral, permitindo o controle mais afiado do trabalho, além da racionalização provocar a simplificação das atividades. Na realidade, consideramos aqui a instabilidade com a renda e com a demanda de trabalho tanto consequências do ajuste do capital a sua crise, como também meios de gestão do trabalho que favorecem o disciplinamento dos trabalhadores empregados, desempregados e subempregados, como expressão direta da dinâmica lógica e histórica da lei geral do valor.

Um segundo condicionante importante para o impulso da plataformização são as reformas neoliberais da legislação do trabalho no mundo, que foram liberando as práticas flexíveis de trabalho. E, isso é importante de ser considerado porque as inovações ocorrem num contexto socioeconômico e político-institucional favorável a elas, ou seja, as condições em que se dão esses trabalhos flexíveis e precários plataformizados, de fato, dependem das ações do Estado e da dinâmica social depressiva da resistência e da luta por direitos (HARVEY, 2016).

A Lei $13.467 / 2017$, que alterou a Consolidação das Leis do Trabalho (CLT) de 1943 em pontos fundamentais, inseriu um novo padrão de gestão da força de trabalho, aprofundando medidas de flexibilização da legislação que desde os anos de 1990 foram sendo institucionalizadas de modo a autorizar a terceirização, o trabalho aos domingos, a contratação por tempo determinado, a admissão por CNPJ (pejotização), a institucionalização do Microempreendedor Individual (MEI) entre outros pontos (BARBOSA e SILVA, 2020). A reforma

competitividade e da aceitação dos riscos (custeando os meios de trabalho, respondendo pelos empecilhos do processo de trabalho e pelas requisições de reprodução social)visando chegar, idilicamente,à independência desejada. Dardot e Laval(2016) mostraram a astúcia dos aparelhos de cultura, educação e entretenimento nessa direção, somados aos próprios institutos legais - programa de formação empreendedora e estatuto de microempreendedor individual - e consultorias de Organizações não Governamentais e para-estatais (Cf. também: HARVEY, 2005). 
de 2017 é a mais robusta alteração legislativa do trabalho no país e ocorre no curso da artimanha política que levou Michel Temer (2017/2018) à Presidência da República ${ }^{24}$, num quadro social dramático que envolve o alto crescimento do exército industrial de reserva mundial; a sofisticada incorporação tecnológica nas empresas, diminuindo trabalho vivo e ampliando o desemprego estrutural; além da forte heterogeneidade e fragmentação do trabalho proletário, concomitantemente ao abatimento da luta sindical (ANTUNES, 2018).

Esse contexto possibilitou que a reforma trabalhista legalizasse práticas até então ilícitas de trabalho no país, mas já incorporadas na divisão internacional do trabalho como dinâmica do trabalho social médio. De maneira geral, as principais alterações da Lei $13.467 / 2017$ seguiram os postulados de flexibilidade nas modalidades de contratação, despadronização da jornada e remuneração também variável. As medidas centrais estão voltadas para a redução do tempo de trabalho não produtivo, diminuindo o tempo destinado a descanso, alimentação, férias e de espera por atividade. Ao lado disso, a reforma criou a possibilidade da remuneração zero com a institucionalização do trabalho intermitente em que a subordinação não é contínua, mas por hora em que o trabalhador é acionado pela empresa para uma atividade ${ }^{25}$.

\footnotetext{
${ }^{24}$ O impeachment de Dilma Rousseff em 2016 expressa o esgotamento do projeto de conciliação de classes do Partido dos Trabalhadores. Entendemos que as exigências do valor requeriam ações mais contundentes sobre, por exemplo, a regulação do trabalho e a reforma trabalhista é expressão disso. A repercussão da crise das hipotecas de 2008 chega tardiamente ao país e abre um forte descenso econômico no quadro da contenção dos investimentos internacionais. Sem conseguir deslocar as contradições o governo Dilma abriu a arena para a pressão do capital sobre o bloco político e as instituições políticas e jurídicas da República impuseram o afastamento do cargo valendo-se do dispositivo aparente de improbidade administrativa e ferimento à lei neoliberal da responsabilidade fiscal. Nesse sentido, a reforma trabalhista regressiva de 2017 faz parte da agenda anticíclica do capital que acelera a flexibilização das relações de trabalho.

${ }^{25} \mathrm{~A}$ experiência desse tipo de contrato começa na Inglaterra zero hour contract. Na Itália chamam de trabalho por voucher demonstrando volatilidade desse tipo de forma de contratação. Em verdade, o trabalho intermitente favorece a transformação de variadas ocupações de diferentes níveis de qualificação, como médicos, enfermeiros, advogados, jornalistas, trabalhadores de cuidados, motoristas, limpeza e consertos domésticos. As plataformas e os smartphones possibilitam concretamente essa forma de contratação, que foi legalizada na referida reforma trabalhista.
} 
$E$, do ponto de vista político, estabeleceu a prevalência do negociado sobre o legislado, facilitando o livre despotismo patronal sobre o trabalhador individual. O caldeirão de ajustes do capital também viabilizou a limitação do acesso do trabalhador à justiça do trabalho instituindo a responsabilidade do mesmo com as custas, caso não tenha ganho de causa ${ }^{26}$. Esses dispositivos se coadunam com a extinção do imposto sindical na reforma terminando com a contribuição compulsória do trabalhador, o que fez minguar as contas dos sindicatos, aprofundando a crise política da organização dos trabalhadores $^{27}$ (ANTUNES, 2018; KREIN et al, 2019).

$\mathrm{Na}$ esteira dessa flexibilização legislativa instituiu-se ainda os trabalhos digitais como o teletrabalho e o trabalho home office que independem da presença física na empresa e nos quais, inclusive, não se contabiliza hora extra. Aliás, o tempo de trabalho fora do espaço específico do trabalho, sugere que caem por terra as segmentações que organizavam a vida do trabalhador em tempos de trabalho e de não trabalho ampliando a expropriação do seu tempo de vida. A lei é silenciosa sobre a cobertura de custos na execução desses trabalhos à distância o que é um modo de externalizar para os trabalhadores a responsabilidade com os meios de trabalho ${ }^{28}$.O certo é que as TICS

\footnotetext{
${ }^{26} \mathrm{Em}$ dois anos de reforma trabalhista, o número de novas ações trabalhistas na justiça do trabalho caiu 32\%: em 2017 existiam 2,2 milhões de processos nas Varas do Trabalho e em 2019 esse número era de 1,5 milhão. A regra que vincula a parte vencida ao pagamento dos honorários do advogado da outra parte, "Além disso, a nova legislação pode obrigar o trabaIhador a pagar às custas do processo" (VALOR, 2020). Ou seja, em pouco tempo o efeito da lei foi consequente com os propósitos porque desocupou o capital com os conflitos das relações de trabalho e com a destinação de parcela do mais valor para esse fim, diminuindo seus custos com o trabalho.

${ }^{27} \mathrm{Um}$ balanço sobre o impacto da reforma trabalhista nos sindicatos pode ser conferida em GALVÃO (2020). O IBGE, sobre a questão da base de sindicalizados, aferiu que "O número de trabalhadores associados a sindicatos trabalhistas teve queda de $21,7 \%$ desde a reforma trabalhista, ocorrida em 2017. Isso corresponde a um contingente de, aproximadamente, 2,9 milhões de profissionais que, em três anos, cancelaram a adesão à respectiva entidade de classe. É o que apontam os dados divulgados nesta quarta-feira (26) pelo Instituto Brasileiro de Geografia e Estatística (IBGE)" (G1, 2020) ${ }^{28} \mathrm{O}$ Ministério Público do Trabalho, a propósito das atividades de home office de parte dos trabalhadores durante o isolamento social da pandemia do coronavírus publicou duas notas técnicas(11 e 17) importantes sobre esse tema, uma específica sobre o trabalho docente e outra sobre os trabalhos remotos em geral, destacando quesitos sobre as condições e relações de trabalho, incluindo a limitação da jornada e a designação de fronteiras sobre a vida privada. A capilaridade dessas normativas sobre os contextos de trabalho parece ainda inexistente, tendo em conta a experiência ao nosso entorno nesse período. No entanto, resta
} 
foram fundamentais para viabilizar a instrumentalização desse tipo de trabalho e a reforma trabalhista foi decisiva para criar as condições legais dessa modalidade de exercício laborativo.

Os estudos na área mostram que a flexibilização do trabalho induzida pela reforma trabalhista de 2017, em verdade, provoca a ampliação da heterogeneidade das formas de contratação, das relações de trabalho e da remuneração do trabalhador (KREIN et al, 2019). Isso significa dizer que há uma inflexão importante que amplia o leque de experiências laborativas dos que vivem do trabalho, dilatando, ao mesmo tempo, a fragmentação proletária, já reconhecida anteriormente por Braga (2012) e Antunes (2018). O que leva Garcia (2020) a dizer que o ponto comum dessa nova inflexão no trabalho com a plataformização, em meio ao aprofundamento da heterogeneidade de ocupações convertidas a isso, consiste em sua precarização, de modo que não mais o ofício ou o regime de emprego seria bases de uma experiência comum, mas a vida e o trabalho precário.

No entanto, é crucial sublinhar que a heterogeneidade do mercado de trabalho brasileiro não é, em si, um fato novo. Isso é decisivo na nossa análise para que tenhamos noção da envergadura das mudanças e sobre que tecido social elas estão sendo operadas. Conforme mostraram Barbosa (2008) e Cardoso (2013) a experiência brasileira expõe o modo desigual com que o desenvolvimento tipicamente capitalista é empreendido nas formações sociais, aqui reproduzido numa plêiade de práticas diversas de trabalho, algumas repondo o arcaísmo do trabalho sem forma emprego (trabalho informal) e outros dentro do estatuto do emprego (esferas pública e privada). Ao longo do século XX conforme o capitalismo se expandiu essa heterogeneidade foi reproduzida como dinâmica social característica, sem superar a chamada informalidade do trabalho. Em termos de dimensionamento pode-se dizer que o mercado de trabalho no Brasil, historicamente, vacilou entre 40 e 50 por cento da força de trabalho na informalidade, portanto, sem contrato e regulação pública de sua subordinação, mantendo-se sem segurança de renda, jornada e proteção social quando do afastamento do trabalho (por morte, doença, aciden-

ver como isso vai se encaminhar, posteriormente, ao quadro de exceção pandêmico (MTP 2020a e MPT 2020 b) 
te ou envelhecimento). Essa não era uma exceção episódica, mas a estrutura do trabalho no país. O trabalho doméstico, o trabalho ambulante, os pequenos consertos, os cuidados pessoais, variados serviços e comércios presentes na cena urbana brasileira mostrava-se funcional ao desenvolvimento capitalista engendrado na periferia viabilizando a reprodução social nas cidades e mostrava a fratura social das contradições da forma social capitalista, com metade da população trabalhadora fora do lócus direto da produção de valor e da experiência operária das empresas massivas. Além disso, a força de trabaIho empregada com respaldo legal, historicamente, padeceu com um mercado de alta rotatividade, baixa renda e limitada negociação coletiva com sindicatos, portanto, uma experiência social diversa do estatuto salarial, demonstrando a contraface do desenvolvimento capitalista desigual ${ }^{29}$.

De acordo com Huws (2020), a experiência internacional mostra que se tem aprofundado esse quadro para os países do sul e introduzido a expansão dessa precariedade nos países do norte, com esses novos negócios digitais e a gestão do trabalho valendo-se do aumento da população excedente que decorre do desemprego, da pobreza e da migração. Nos termos dos estudos marxistas significa compreender, hoje, a multiplicidade de formas de trabalhos e a ampliação da expropriação do fundo de consumo e de vida do trabalhador, por meio da plataformização do trabalho. A renda baixa, as relações de emprego escamoteadas e a intensificação da jornada sobre o tempo de vida do trabalhador caracterizam indelevelmente a expropriação realizada pelos mecanismos de reprodução ampliada do capital.

Essa heterogeneidade do trabalho, que é ajustada agora brota da mutação tecnológica e do restante da agenda contratendencial do capital (desemprego e trabalho precário), para deslocar as contradi-

\footnotetext{
${ }^{29}$ Frente a essa experiência histórica não é difícil entender o depoimento de muitos traba Ihadores com experiências degradantes, mas que manifestam que a renda retirada no trabaIho realizado por meio de aplicativo de entregas e de transporte é a mais alta por ele auferida, sugerindo que esse trabalho extenuante de 10 ou 12 horas diárias, em seis dias por semana, seria mais recompensador que os anteriores ou ao menos não lhe seria estranho ( $A B$ Í LIO, 2020).Isso é importante para entendermos de que referências de trabalho estamos lidando no quadro da estrutura da formação social e econômica brasileira e os desafios de pesquisa para pensar essa fratura social e as ruínas humanas subjacentes.
} 
ções da crise estrutural do capital. A reforma trabalhista e as plataformas atuam induzindo o trabalho sem a forma emprego, o que de certo modo é uma reconfiguração da informalidade, agora, como parte legítima do trabalho capitalista típico na totalidade social ${ }^{30}$. Manifesta-se como um ajuste do capital a sua crise e como resposta às novas possibilidades de exercício e controle do trabalho oportunizadas pela remodelação tecnológica em curso, notadamente as TICs e a $I A^{31}$.

\section{Considerações Finais}

A disseminação da digitalização no trabalho é uma investida genérica sobre todas as dinâmicas socioeconômicas e, por isso mesmo, estratégica para problematizarmos as inflexões na gestão do trabalho como totalidade ${ }^{32}$. Isso é importante de ser realizado, tanto focando trabalhos específicos, em termos de especialização e formas de contratação, como operando uma interpretação longitudinal que nos permita ver a experiência comum, para que seja possível demarcar investigações pertinentes às condições e às relações de trabalho, mediadas pela digitalização no conjunto das atividades laborais.

\footnotetext{
${ }^{30}$ No âmbito dessas mudanças no capitalismo mundial emergiu, nos EUA, a expressão Gigeconomy (economia dos bicos) que hoje nomeia a sobrevivência por meio de bicos, contratos de trabalho temporário, atividades inscritas em plataformas em que se tem renda caso seja demandado, cujo exemplo de modelo de negócio é a plataforma empresa Uber. O termo mostra a dimensão da mundialização da viração, da experiência dos trabalhadores que se viram diariamente para garantir o sustento.

${ }^{31}$ Posteriormente, será importante problematizar isso no contexto da pandemia do coronavirus (covid19), em razão do isolamento social, quando os trabalhadores empregados tiveram contratos suspensos, férias antecipadas, remuneração reduzida ou dispensa definitiva por demissão (DIEESE, 2020). A superpopulação relativa que já levava a vida na viração do trabalho informal viu as ocupações derreterem com a queda da circulação levando à limitação parcial ou total da renda (KREIN e BORSARI, 2020; ANTUNES, 2018). O cenário de recessão econômica foi fortalecido com o crescimento do trabalho home office, ampliação dos serviços por meio de tecnologia remota, aumento do desemprego por esses fatores e pelo desaquecimento econômico (DAVIS, 2020).

${ }^{32}$ Huws (2020) considera importante descentrar a reflexão dos entregadores ou motoristas o eixo do trabalho plataformizado, para perceber a multiplicidade de ocupações mobilizadas nos processos de trabalho, incluindo várias formas de contratação e marcadores sociais da força de trabalho.
} 
Esse movimento de análise sobre a gestão capitalista do trabalho, atualmente, é ainda um campo aberto e a dinâmica da plataformização do trabalho, em curso, mobiliza nossas investigações para entender a função de ações como: 1) levantamento e organização de grande volume de dados sobre o desempenho do trabalhador na empresa e na vida privada; 2) uso de ferramentas-algoritmos para processar e analisar esses dados para detectar padrões e perfis de correlação de dados; 3)automatização de decisões, que tendem a implantar práticas de alerta, punição e rescisão automáticos. Em geral, com critérios não totalmente transparentes e em permanente mudança, tendo em vista a renovação frequente dos dados no aparato de navegação da internet (ADAMIS-PRASSI, 2020).

A simplificação e a padronização das atividades é um desdobramento desse quadro que levará a uma profunda mudança nos trabalhos complexos, por exemplo. Motivo que nos parece fundamental para que as pesquisas da universidade também avancem no sentido de entender seu lugar social nesse quadro societário. $O$ início de atividades online de políticas públicas e previdenciárias, assim como a modalidade home office de variados trabalhos das esferas pública e privada desafiam nosso entendimento sobre o enxugamento dos empregos, a natureza das profissões e a qualidade dos serviços prestados.

Ainda que não tenha sido o foco neste texto, o processo de organização dos trabalhadores que atuam com plataformas como delivery e transporte por aplicativo tem sido um desafio político e investigativo importante (ANTUNES, 2020). Afinal estamos lidando com as tecnologias mais avançadas e, nesse quadro, foram reinventados o trabalho árduo e as longas jornadas do trabalho por peça (trabalho por demanda). Formas brutais de trabalho para as quais não há barreiras técnicas para a sua dissolução, mas obstáculos sociais a serem confrontados, pois "A maquinaria mais desenvolvida, portanto, força o trabalhador a trabalhar mais do que o selvagem, e mais do que ele mesmo com as ferramentas mais simples e precárias."(MARX, 2011, p. 709) 


\section{Referências}

ABILIO, Ludmila Costhek. Uberização: do empreendedorismo para o autogerenciamento subordinado. Psicoperspectivas, v.18, n.3, 2019.

- Uberização do trabalho: subsunção real da viração. Passa

Palavra. 2017. Disponível em: <https://passapalavra.info/ 2017/02/110685/>. Acesso em:21 ago. 2020.

. Uberização: a era do trabalhador just-in-time? Estudos

Avançados. São Paulo, v. 34, n. 98, p. 111-126, abr. 2020.

ADAMIS-PRASSI, Jeremias. Gestão algorítmica e o futuro do trabalho. CARELLI, Rodrigo L. et al (org). Futuro do trabalho: os efeitos da revolução digital na sociedade. Brasília : ESMPU, 2020.

ANTUNES, Ricardo. 0 privilégio da servidão. São Paulo: Boitempo, 2018.

. (org). Uberização, trabalho digital e indústria 4.0. São Paulo: Boitempo, 2020.

BARBOSA, Alexandre Freitas. A formação do mercado de trabalho no Brasil. São Paulo: Alameda, 2008.

BRAGA, Ruy. Política do precariado. São Paulo: Boitempo, 2012.

BRAVERMAN, Harry. Trabalho e capital monopolista. Rio de Janeiro: Guanabara, 1977.

BRENNER, Robert. $\mathbf{O}$ boom e a bolha: os EUA na economia mundial. São Paulo: Record, 2002.

. CALDAS, Camilo e CALDAS, Pedro. Estado, democracia e tecnologia: conflitos políticos e vulnerabilidade no contexto do big-data, das fake news e das shitstorms. Perspectiva em Ciência da Informação, v. 34, n. 2. Belo Horizonte: UFMG, abr./jun. 2019. Disponível em: <https://www.scielo.br/scielo.php?script=sci_arttext\&pid=S141399362019000200196>. Acesso em: 21 ago. 2020.>

CARDOSO, A. Ensaios de sociologia do mercado de trabalho brasileiro. Rio de Janeiro: FGV, 2013. 
CARELLI, Rodrigo L. et al (org). Futuro do trabalho: os efeitos da revolução digital na sociedade. Brasília: ESMPU, 2020.

CHAN, Jenny et al. A política da produção global: Apple, Foxconn e a nova classe trabalhadora chinesa. ANTUNES, Ricardo (ORG). São Paulo: Boitempo, 2019.

CHESNAIS, François. As dimensões financeiras do impasse do capitalismo: uma reflexão teórica do atual estágio do capitalismo financeiro a partir das ferramentas conceituais do marxismo. Revista Movimento, 3/03/2018. Disponível em: <https://movimentorevista.com.br/ 2018/03/as-dimensoes-financeiras-do-impasse-do-capitalismo-mundializacao-do-capital-chesnais/>. Acesso em: 21 ago. 2020.

O estado da economia mundial às vésperas da pandemia.

Carta Maior, 14/04/2020. Disponível em: <https://www.cartamaior.com.br/?/Editoria/Economia-Politica/O-estado-da-economia-mundial-as-vesperas-da-pandemia/7/47164>. Acesso em: 21 ago. 2020.

CONTRACAMPO. Revista do PPGCOM, v. 39, n. 2, abril/2020. Niterói: PPGCOM-UFF, 2020. Disponível em: <https://periodicos.uff.br/contracampo/issue/view/2150/showToc>. Acesso em: 21 ago. 2020.

DANTAS, Marcos e RAULINO, Gabriela Trabalho da audiência e renda informacional no Facebook e no Youtube. Revista Eptic vol. 22, n.1, jan./abr/2020. Aracaju: UFS/PPGC/OBSCOM, 2020.

DARDOT, Pierre e LAVAL, Christian. A nova razão do mundo. São Paulo: Boitempo, 2016.

DEFFANTI, Alessandro. Entrevista - Como é trabalhar em um galpão da Amazon. Digilabour. Vale do Rio dos Sinos: Unisinos, 2019. Disponível em: <https://digilabour.com.br/2019/11/22/como-e-trabalharem-um-galpao-da-amazon-entrevista-com-alessandro-delfanti/>. Acesso em: 21 ago. 2020.

DE STEFANO, Valério. Automação, inteligência artificial e proteção laboral: patrões algorítmicos e o que fazer com eles. CARELLI, Rodrigo L. et al (org). Futuro do trabalho: os efeitos da revolução digital na sociedade. Brasília : ESMPU, 2020. 
DRUCK, Graça. A precarização do trabalho no Brasil. ANTUNES, Ricardo (org.). Riqueza e miséria do trabalho no Brasil II. São Paulo: Boitempo, 2013.

FAUSTO, Ruy. A pós-grande indústria nos Grundisses (e para além deles). Lua Nova, n. 19. São Paulo: Cedec, 1984.

FESTI, Ricardo. Contribuições críticas da Sociologia do Trabalho sobre automação. ANTUNES, Ricardo (org). Uberização, trabalho digital e indústria 4.0. São Paulo: Boitempo, 2020.

FILGUEIRAS, Vitor e ANTUNES, Ricardo. Plataformas digitais, uberização do trabalho e regulação do capitalismo contemporâneo. Contracampo, v. 39, n. 1. Niterói: UFF/PPGCOM, 2020. Disponível em: <https://periodicos.uff.br/contracampo/article/view/38901>. Acesso em: 21 ago. 2020.

FONTES, Virginia. Capitalismo em tempos de uberização: do emprego ao trabalho. Marx e Marxismo, v. 5, n. 8, jan/jun/2017. Niterói: UFF/Niep, 2017.

GALVÃO, Andréa. Reforma trabalhista 2 anos depois: nada a comemorar, muito a combater. Democracia e Mundo do Trabalho, maio. São Paulo, 2020. Disponível em: <http:// www.dmtemdebate.com.br/reforma-trabalhista-2-anos-depoisnada-a-comemorar-muito-a-combater/>. Acesso em: 21 ago. 2020.

GARCIA, Lúcia. Brasil tem 3 milhões de trabalhadores e trabalhadoras vinculadod a aplicativos. DMT entrevista, por Igor Natusch, em 16/09/2020. Disponível em: <http://www.dmtemdebate.com.br/brasil-tem-3-milhoes-de-trabalhadores-e-trabalhadoras-vinculados-aaplicativos-entrevista-especial-com-lucia-garcia/>. Acesso em: 21 ago. 2020.

G1, GLOBO. Brasil perdeu 21,7\% dos trabalhadores sindicalizados após a reforma trabalhista, diz IBGE. Rio de Janeiro: Globo, 2020. Disponível em: <https://g1.globo.com/economia/noticia/2020/08/26/ brasil-perdeu-217percent-dos-trabalhadores-sindicalizados-apos-areforma-trabalhista-diz-ibge.ghtml>. Acesso em: 21 ago. 2020. 
GONSALES, Marco. Indústria 4.0: empresas plataformas, consentimento e resistência. ANTUNES, Ricardo (org). Uberização, trabalho digital e indústria 4.0. São Paulo: Boitempo, 2020.

GRAHAM, Mark e ANWAR, Mohammad Amir. Trabalho digital. ANTUNES, Ricardo (org). Uberização, trabalho digital e indústria 4.0. São Paulo: Boitempo, 2020.

GRAVAS, Douglas. Aplicativos como Uber e iFood são fonte de renda de quase 4 milhões de autônomos. 0 Estado de São Paulo, 28 de abril de 2029. Disponível em: <https://www.ilocomotiva.com.br/single-post/2019/04/29/ESTAD\%C3\%830-Na-crise-aplicativos-comoUber-e-iFood-viram-maior-empregador-do-pa\%C3\%ADs>. Acesso em: 21 ago. 2020.

GROHMANN, Rafael. Plataformização do trabalho: entre a dataficação, a financeirização e a racionalidade neoliberal. Revista Epitc, Aracaju: UFS/PPGC/OBCOM, v. 22, n. 1, jan./abr. 2020.

HARVEY, David. O neoliberalismo: história e implicações. São Paulo: Loyola, 2005. po, 2016.

17 contradições e o fim do capitalismo. São Paulo: Boitem-

HUWS, Ursula. A formação do cibertariado: trabalho virtual em um mundo real. Campinas: Unicamp, 2017.

. Reinventingthe Welfare State: digital platafformsandpublicpolices. Londres: Pluto Press, 2020.

. et al. The platformisationofwork in Europe: resultsfromreseach in 13 european countries. Londres: Foundation for EuropeanProgressiveStudies, 2019. Disponível em: <https://www.fepseurope.eu/attachments/publications/the\%20platformisation\%20of \%20work\%20in\%20europe\%20-\%20final\%20corrected.pdf>. Acesso em: 21 ago. 2020.

IBGE. Uso de internet, televisão e celular no Brasil. PNAD Contínua 2018. Brasília: IBGE, 2020. 
IEDI. Digitalização e as cadeias globais de valor. Carta IEDI, edição 989. São Paulo: IEDI, 2020. Disponível em: <iedi.org.br/cartas/ carta_iedi_n_989.html>.Acesso em: 21 ago. 2020.

KREIN, José Dari et al (org.) Reforma trabalhista no Brasil: promessas e realidade. Campinas, SP: Curt Nimuendajú, 2019.

. e BORSARI, Pietro. Pandemia e desemprego: análise e perspectiva. Cesit. Campinas: Unicmap/Cesit, 2020. Disponível em: $<$ https://www.cesit.net.br/pandemia-e-desemprego-analise-e-perspectivas/>. Acesso em: 21 ago. 2020.

LIMA, Jacob e BRIDI, Maria Aparecida. Trabalho digital e emprego: a reforma trabalhista e o aprofundamento da precariedade. Caderno CRH, Salvador, UFBA, v. 32, n. 86, maio/ago. 2019.

MANDEL, E. Capitalismo tardio. São Paulo: Abril, 1985.

MARX, Karl. O Capital: crítica da economia política. Livro I. Rio de Janeiro: Civilização Brasileira, 2008.

. O Capital: crítica da economia política. Livro III. Rio de Janeiro: Civilização Brasileira, 2008.

. Grundisse. São Paulo/Rio de Janeiro: Boitempo/UFRJ, 2011.

MACKINSEY. Brazil digital Report. Vale do Silício, 2019. Disponível em: < https://brazilatsiliconvalley.com>. Acesso em: 21 ago. 2020.

ONU. Digital economyreport 2019. New York: UNCTAD, 2019.

MTP. Nota técnica 11 - GT Covid 19. Brasília: Procuradoria Geral do Trabalho, 2020a. Disponível em: <https://mpt.mp.br/pgt/noticias/ nota-tecnica-n-11-2020-trabalho-on-line-de-professores-gt-covid-19mpt.pdf>. Acesso em: 21 ago. 2020.

. Nota técnica 17 - GT Covid 19. Brasília: Procuradoria Geral do Trabalho, 2020b. Disponível em: <https://mpt.mp.br/pgt/ noticias/nota-tecnica-n-17-sobre-trabalho-remoto-gt-covid-19-e-gtnanotecnologia-2.pdf>. Acesso em: 21 ago. 2020.

OIT. As plataformas digitais e o futuro do trabalho. Genebra, BIT, 2020. 
VALOR ECONÔMICO. Número de novas ações trabalhistas cai 32\% dois anos após a reforma. Jornal Valor Econômico, São Paulo, 04 jan. 2020. Disponível em: <https://valor.globo.com/brasil/noticia/ 2020/01/04/numero-de-novas-acoes-trabalhistas-cai-32percent-doisanos-apos-reforma.ghtml>. Acesso em: 21 ago. 2020.

ROBERTS, Michael. Lucratividade: o investimento e a pandemia. In: Economia e Complexidade, 25/05/2020. Disponível em: <https:// eleuterioprado.files.wordpress.com/2020/05/lucratividade-o-investimento-e-a-pandemia.pdf>. Acesso em: 12 set. 2020.

SERFATI, C. O papel ativo dos grupos predominantemente industriais na financeirização da economia. In: CHESNAIS, F. (Ed.). A mundialização financeira: gênese, custos e riscos. São Paulo: Xamã, 1998.

TOZI, Fábio. Uma geografia da uberização no Brasil. Outras Palavras, São Paulo, 07 out. 2020. Disponível em: <https://outraspalavras.net/ cidadesemtranse/uma-geografia-da-uberizacao-no-brasil/? fbclid=IwAR1xqcvK03InfnpFlyb66wpb0Mao97kiJKJhiZAPIhkj8cL2kHezJOjdlyA>. Acesso em: 12 set. 2020.

WOODCOK, Jamie. O panóptico algoritmo da Deliveroo: mensuração, precariedade e a ilusão do controle. ANTUNES, Ricardo (ORG). Uberização, trabalho digital e indústria 4.0. São Paulo: Boitempo, 2020.

ZUBOFF, Shoshana. Big Other: capitalismo de vigilância e perspectivas para uma civilização de informação. BRUNO, Fernanda. (ORG.). Tecnopolíticas da vigilância. São Paulo: Boitempo, 2018.

\section{Sobre a autora:}

Rosangela Nair de Carvalho Barbosa - Professora associada da Faculdade de Serviço Social da UERJ, onde atua na graduação, na Pós-Graduação (mestrado e doutorado) e no Programa de Estudos de TrabaIho e Política. Mestre em Sociologia pela UFRJ, Doutora em Serviço Social pela PUC-SP e Pós-Doutora em Sociologia do Trabalho pela UFRJ. Bolsista Produtividade CNPq2.

E-mail: rosangelancb@uol.com.br 